Vol. 9(5), pp. 67-81, June, 2017

DOI: 10.5897/JASD2016.0422

Article Number: C6466D964602

ISSN $2141-2189$

Copyright (c) 2017

Author(s) retain the copyright of this article

http://www.academicjournlas.org/JASD
Journal of African Studies and

Development

\title{
Factors contributing to irregular migration: A case of Kasulu District, Tanzania
}

\author{
Robby S. Magweiga ${ }^{1 *}$ and Justin K. Urassa ${ }^{2}$ \\ ${ }^{1}$ Ministry of Home Affairs, Tanzania. \\ ${ }^{2}$ Department of Policy, Planning and Management, College of Social Sciences and Humanities, University of Agriculture, \\ Tanzania.
}

Received 20 November, 2016; Accepted 7 April, 2017

\begin{abstract}
Despite the fact that irregular migrants (IRMs) have often been facing a lot of challenges in sustaining their livelihood in Kasulu District, yet in recent years, there has been an increase of IRMs from within and outside Kasulu District in search of casual labour in the local community. The study therefore was undertaken in four villages in Kasulu, Kitanga, Kagera-Nkanda, Mvugwe and Nyachenda. Specifically, the study aimed to determine the driving factors of irregular migration, to assess smallholder farmer's attitude towards IRMs, and finally, to identify how the IRMs are affected by their interaction with smallholder farmers in Kasulu District. The study on which the paper is based used a cross- sectional research design whereby data was collected at one point and time. The study employed random sampling, purposive and snowball sampling techniques to get 120 respondents. Data were collected using a questionnaire, key informant interviews, focus group discussions and direct observations. Quantitative data were analysed using statistical package for social science (SPSS) whereby descriptive statistics were determined. Qualitative data were analysed using content analysis. The results show social, cultural, economical and political factors are responsible for the irregular migration observed in Kasulu District. It is thus recommended that, the immigration department and other security organs working along the border should establish several entry posts either permanently or mobile along the country borders to deter IRMs and ease visa issuance process for those migrants wishing to enter the country legally.
\end{abstract}

Key words: Irregular migration, Kasulu, Tanzania.

\section{INTRODUCTION}

From the beginning of human history people have been moving from one place to another and this mobility is a common phenomenon to this day. What has changed is the formation of states, nations, alliances, and establishment of sovereignty, citizenship, borders as well as laws, which among other functions, have been used to govern and control the movements and settlement of people from one country to another (Ahlberg and Runell, 2009). Available literature on irregular migrants (IRMs) describes irregular migration as a common and necessary feature of modern life which is universally acknowledged and has extensively contributed to the

*Corresponding author. E-mail: robbysamweli@yahoo.co.uk.

Authors agree that this article remain permanently open access under the terms of the Creative Commons Attribution License 4.0 International License 
development of different societies worldwide in the form of farm cheap labour (Mattson, 2008). However, studies on irregular migration are constrained by inaccurate data (Mouaatamid, 2010; Koser, 2005). Moreover, it was estimated that by the year 2010 , that about 214 to 321 million people (10 to $15 \%$ ) of the world's total population were international IRMs living irregularly outside their countries of birth (IOM, 2010). According to the UNHCR (2001) statistical yearbook, only $40 \%$ of all the persons of concern to the UNHCR worldwide were living in refugee camps. About $47 \%$ of the people were either dispersed in rural areas or were in places not specified. Literature on IRMs shows that strict barriers on legal entry of irregular migration have been placed by many states worldwide; there is however a large number of irregular migrants in different countries who are used as cheap labourers (Patrick and Geronimi, 2003).

Tanzania shares borders with eight surrounding states most of which have at one point or another experienced conflicts which have produced refugees who sought refuge in Tanzania (Rutinwa, 2005). However, not all of those fleeing their countries come through the official channels as per UNHCR's guidelines and due to the porous nature of Tanzania's boarders many IRMs have found their way into the country. In addition, the high degree of cultural affinity within the Great Lakes region makes it easier for some IRMs (Johnson, 2008; URT, 2010). Moreover, due to Tanzania's lack of adequate resources and capacity to patrol her borders irregular migration from the neighbouring war torn countries of Burundi, Rwanda and Democratic Republic of Congo can go unchecked (UNHCR, 2006: IOM, 2010; Mouaatamid, 2010).

Since 1972, following the civil war in Burundi about 300,000 Burundians were estimated to have spontaneously settled in Tanzanian villages along the border between Tanzania and Burundi. These were the refugees who have been either living in the local villages or getting outside refugee camps irregularly for several years, very often without formalising their stay, working and movement status (Rutinwa, 2005: Jennifer, 2007: Johnson, 2008). Existing literature (Johnson, 2008; URT, 2010), explicitly shows that, irregular migration in Tanzania is not simply a concern for only those who come into the country, but also those who exit from the refugee camps and for those who refuse to leave the country. It has also been stated that, some of these IRMs have established their own homes, are owning or renting land and are involved in farming as casual labourers, livestock keepers, rendering human labour to farmers in the rural areas, and others are married to Tanzanians without legal documents that allow them to engage in the above-mentioned activities (NRC, 2006: Jacob, 2009: URT, 2010).

Generally, from an economic perspective literature shows that irregular migration is actually quite useful in many states of destination due to liberalization of their economies which in one way or another leads to the demand of various forms of skilled and semi-skilled labourers for which irregular migration becomes a potential source (Koser, 2005; Berry, 2008). However, IRMs more often than not end up facing lots of challenges. For example in Kasulu District; they end up being a source of hard labour in agricultural related activities, receiving poor remuneration in return, harsh treatment and being subjected to deportation (NRC, 2006, Mouaatamid, 2010; URT, 2010). Despite the above, Kasulu District has been experiencing an increase of IRMs from within and outside the district searching for casual employment in the local community (Jacob, 2009: URT, 2010; Mouaatamid, 2010). Nonetheless, existing literature on irregular migration in Tanzania has limited information on IRMs, as it does not explicitly provide empirical evidence on what drives the irregular migration while there are official channels of entering another state even under conditions of war or social strive. Therefore, the study on which the paper is based aimed to fill this knowledge gap. In addition, findings from the study could shed some light on the unknown factors behind irregular migration in Kasulu District thus helping the central and local government, UNHCR, and other stakeholders interested in migration and its socio-economic importance to both the IRMs and host local community.

\section{RESEARCH METHODOLOGY}

\section{Description of the study area}

Kasulu District is one of the three districts of Kigoma Region. It comprises seven divisions with 30 wards divided into 92 villages and covers approximately $9324 \mathrm{~km}^{2}$. The district borders Burundi to the West for about $150 \mathrm{~km}$ porous land border, a large game reserve (Moyowosi) to the East. To the North-East it shares borders with Kibondo District and Kigoma District to the South. The study was carried out in five wards namely Kitanga, Nyamidaho, Kagerankanda, Nyachenda and Kitagata. Kasulu District was selected because of hosting both irregular migrants who are estimated to be over 15,000 (URT, 2010) and the long term refugees residing in Kasulu villages since 1972 (Most of these have been moving and working from one village to another without legal documents allowing them to travel, stay or work while in Kasulu).

Kasulu District also hosts, Burundian refugees who arrived since 1993 and who are still living in refugee camps and unwilling to repatriate voluntarily to Burundi. These refugees have been observed moving out of their camps to nearby villages in search of employment as casual labourers without official documents. In addition, as pointed earlier Kasulu district has a long porous border with only one official entry point. Consequently, this has led to large numbers of IRMs coming directly from Burundi in search for employment (as casual labourers) in the villages. Furthermore, agriculture being a major livelihood source of local communities has led to high demand of cheap labourers and presumably the increase of IRMs.

\section{Research design, sampling and sample size}

The study adopted a cross-sectional research design; the design was the most appropriate for the study on which the current paper 
is based. Generally, the design is less costly and allows one to collect the required data in a relatively short period of time. According to Bailey (1998), the design is useful for descriptive purposes as well as for determination of relationship between and among variables and it allows a researcher to collect data at one point in time. The study's population included all IRMs (noncitizens) employed by smallholder farmers in the studied villages (Kitanga, Nyamidaho, Kagera-nkanda, Nyachenda and Kitagata), smallholder farmers who employ the IRMs and those who did not.

According to Bailey (1998), the minimum sample or sub sample for a research in which statistical data analysis is to be done is thirty (30) cases. Therefore, the study used 120 respondents from four villages. To obtain the above sample, a combination of three different sampling techniques, was adopted, that is, purposive sampling, simple random sampling and snowball sampling. Purposive sampling was used in selecting two divisions out of the available seven, four wards out of thirty and four villages out of ninety, all the above have a high number of IRMs. Key informants and participants to focus group discussions were selected purposively. Simple random sampling was used to get the respondents from the households employing IRMs in agricultural production and those not. Snowball sampling was used to get prominent IRMs who were living and employed by smallholder farmers as cheap labourers but who were hard to find through purposive and simple random sampling as they did not stick with one farmer in one place.

\section{Data collection}

Data was collected using a pre-structured questionnaire with open and close ended questions. Generally, before the actual household survey a pilot study to pre-test the questionnaire was undertaken in three villages after getting the required clearance from Sokoine University of agriculture, the District Commissioner's Office and from the Village governments'. The pilot aimed at testing the reliability and validity of the data collections tools in terms of precision, objectivity and relevancy. Based on the findings, some revisions were made to the questionnaire.

In addition to the above, data coolected through the questionnaire were complemnented by information collected through direct observations, in-depth interviews with key informants and the focus group discussions (FGDs). All these aimed at allowing triagualtion of the study findings. Overall, five FGDs were conducted; these normally involved eight participants each. In addition to the above, 16 in-depth interviews were conducted, four for each of the selected village. The key informants for the in-depth interviews included village leaders, extension officers, teachers, land officers, forest officers, immigration officers, refugees' officers, auxiliary police, militia personnel, and IRMs. FGD participants were got through the help of village/hamlet/IRMs leaders. As pointed out earlier the KIIs and FGDs aimed at complementing the information gathered from the household surveys. Generally, the research adhered to ethical considerations whereby participation was on a voluntary basis and respondents were assured of their anonymity in relation to the information shared

\section{Data analysis}

The study's unit of analysis was the household. Quantitative data collected through the questionnaires were edited, summarised, coded and thereafter analysed using the statistical package for social science (SPSS). SPSS was used to determine descriptive statistics, that is, frequencies, percentages. In addition, the Likert scale was used to determine the smallholder farmers' attitude towards IRMs. On the other hand qualitative data was analysed using content analysis whereby qualitative information from the key informant interviews and FGDs was summarized and organized into meaningful themes. Generally, the qualitative information has been used in this paper to complement what was collected through the questionnaire.

\section{RESULTS AND DISCUSSION}

\section{Respondents demographic and socio-economic characteristics}

The sex of the household head in the family may influence the status of the household in accessing both casual labour and self-employment in agricultural activities. The results in Table 1 show that $87.5,77.5$ and $85 \%$ of household for smallholder farmers employing IRMs, those not using IRMs and IRMs were headed by males. On the other hand, $12.5,22.5$ and $15.5 \%$ of household for smallholder farmers employing IRMs, those not using IRMs and IRMs were headed by females. The findings show that most of those who were IRMs and working as cheap labourers were men and were similarly employed by the majority males compared to females. However, the absence of the majority female labour force in some agricultural activities can have profound effects on the output as the majority were women left in charge of the households.

Results in Table 1 show that most $(82.5 \%)$ respondents' age ranged between 15 and 47 years thus suggesting the majority were in the economically active group bearing main responsibilities for the household livelihoods. The findings are similar to the argument put forward by Rutasitara (2002) the age of an individual has an influence on productivity and is a factor that can explain the level of production and efficiency and that the children and the old tend to be less active in economic activities than those in the middle age who are active, aggressive and motivated by the needs of their families.

Focusing on the marital status of the respondents Table 1 show that less than a quarter $(22.5 \%)$ and over a third $(70 \%)$ of smallholder farmers who employed IRM, and both those not hiring IRM, and the IRMs respectively were living as singles. About three quarters $(72.5 \%)$ of those employing IRMs, and $27.5 \%$ of both smallholder farmers not hiring IRMs and the IRMs were married. According to Table 1 the percentage of the single IRMs is higher than that of smallholder farmers. This could simply be due to the nature and life of the majority of single IRMs, such that they lack family responsibilities, thus making them more flexible to move and hence easily available for employment as casual labourers by smallholder farmers.

Table 1 further shows that $12.5 \%$, of the household of smallholder farmers employing IRMs, and about two third $(65.5 \%)$ of IRMs interviewed had between 1 to 3 people. While 42.5 and $25 \%$ of the same categories of respondents had 4 to 7 people, another 45 and $12.5 \%$ of smallholder farmers employing IRMs and IRMs had 8 and 
Table 1. Respondents demographic and socio-economic characteristics $(n=120)$.

\begin{tabular}{|c|c|c|c|c|}
\hline Characteristic & & $\begin{array}{l}\text { Smallholder farmers } \\
\text { employing IRMs }\left(n_{E}=40\right)\end{array}$ & $\begin{array}{l}\text { Smallholder farmers not } \\
\text { employing IRMs }\left(n_{\mathrm{NE}}=40\right)\end{array}$ & $\begin{array}{c}\text { Irregular migrants } \\
\left(n_{\mathrm{IRM}}=40\right)\end{array}$ \\
\hline \multirow{3}{*}{$\begin{array}{l}\text { Respondent's } \\
\text { sex }\end{array}$} & Male & $35(87.5)$ & $31(77.5)$ & $34(85.0)$ \\
\hline & Female & $5(12.5)$ & $9(22.5)$ & $6(15.0)$ \\
\hline & $15-25$ & $3(7.5)$ & $1(2.5)$ & $5(12.5)$ \\
\hline \multirow{4}{*}{ Age categories } & $26-36$ & $10(25.0)$ & $9(22.5)$ & $17(42.5)$ \\
\hline & $37-47$ & $16(40.0)$ & $17(42.5)$ & $11(27.5)$ \\
\hline & $>47$ & $11(27.5)$ & $13(32.5)$ & $7(17.5)$ \\
\hline & Not married & $9(22.5)$ & $28(70.0)$ & $28(70.0)$ \\
\hline \multirow[t]{4}{*}{ Marital status } & Married & $29(72.5)$ & $11(27.5)$ & $11(27.5)$ \\
\hline & Divorced & $2(5.0)$ & $1(2.5)$ & $1(2.5)$ \\
\hline & $1-3$ & $5(12.5)$ & $10(25.0)$ & $25(62.5)$ \\
\hline & $4-7$ & $17(42.5)$ & $14(35.0)$ & $10(25.0)$ \\
\hline \multirow{5}{*}{ Household size } & 8 and above & $18(45.0)$ & $16(40.0)$ & $5(12.5)$ \\
\hline & Minimum & 2 & 2 & 1 \\
\hline & Maximum & 13 & 12 & 8 \\
\hline & Average & 7.15 & 6.65 & 3.25 \\
\hline & Farming & $31(87.5)$ & $34(85)$ & $32(80)$ \\
\hline \multirow{4}{*}{$\begin{array}{l}\text { Main economic } \\
\text { activity }\end{array}$} & Charcoal making & $1(2.5)$ & $1(2.5)$ & $2(5)$ \\
\hline & Logging & $4(2.5)$ & $1(2.5)$ & $5(12.5)$ \\
\hline & Livestock keeping & $3(7.5)$ & $4(10)$ & $1(2.5)$ \\
\hline & No formal education & $8(20)$ & $7(17.5)$ & $33(82.5)$ \\
\hline \multirow[t]{2}{*}{ Education level } & Primary education & $26(65)$ & $28(70)$ & $6(15)$ \\
\hline & Secondary education & $6(15)$ & $5(12.5)$ & $1(2.5)$ \\
\hline
\end{tabular}

$\mathrm{n}_{\mathrm{E}}=$ Number of respondents employing IRMs; $\mathrm{n}_{\mathrm{NE}}=$ Number of respondents not employing IRMs; $\mathrm{n}_{\mathrm{IRM}}=$ Number of IRMs. Numbers in bracket indicate percent.

more than 8 people in their households. On the other hand about $62 \%$ of IRMs households had 1 to 3 members. This might be due to the fact that most IRMs are either single or married but do not stay with their families due to their temporal nature of living in farm areas, hence their easy movement.

Study results as presented in Table 1 show that agriculture is the main economic activity of the respondents whereby more than four fifths (87.7 and $85 \%$ ) of the surveyed households both employing IRMs and those not had agriculture as they main economic activity. The study also revealed that the majority IRMs are engaged in farming activities as casual labourers, this probably might be due to the fact that they have neither capital nor other alternatives to earn a life. This observation is in line with Bastian and Don (2009) who pointed out that employers have more power over most IRM workers than other workers, as the majority of IRM workers rely on their employers for their continuing stay in alien country. The study findings present a typical lifestyle in a Tanzanian rural area, since over $85 \%$ of the respondents interviewed were engaged in farming activities. The results are consistent with the KDS (2010) profile which estimates that about $90 \%$ of the local communities are engaged in agricultural activities for their livelihood.

Ones literacy level is very useful for smallholder farmers and IRMs choice of a livelihood stategy and his/her productivity in general. Those with better education may easily be able to grasp and implement whatever skills provided to them such as using modern technology in agriculture and employment in general. As it was expected prior to the study, the illiteracy rate was expected to be higher in rural areas; the results in Table 1 show a very high illiteracy level in the surveyed area. Majority of both smallholder farmers employing and those who do not employ IRMs and the IRMs, which is equivalent to $65.5,70$ and $15 \%$ of total respondents had primary school education, those with secondary education school were, $15,12.5$ and $2.5 \%$ respectively for the total respondents employing and those not employing IRMs and the IRMs. The findings of this study show that the majority $82.5 \%$ of the IRMs had no formal education and lacked employable skills which could 
Table 2. Reasons for irregular migration $(n=40)$.

\begin{tabular}{lcc}
\hline Reasons for irregular migration $(\mathbf{n}=\mathbf{4 0})$ & Frequency & Percent \\
\hline Looking for employment as agricultural labourers & 35 & 87.5 \\
Seeking Business & 1 & 2.5 \\
In search of grazing land for livestock keeping & 3 & 7.5 \\
Looking for area for permanent residence & 9 & 22.5 \\
Land scarcity and associated problems & 38 & 95.0 \\
Social and cultural unrest in Burundi & 14 & 35.0 \\
Social exclusion of refugees in the camp & 8 & 20.0 \\
Sporadic political and civil war & 8 & 20.0 \\
Incentives given by smallholder farmers & 38 & 95.0 \\
\hline
\end{tabular}

enable them to be absorbed in the formal job market; hence, they depend mostly on working as farmers' cheap labourers or in agricultural activities for their livelihood.

\section{Causes of irregular migration}

The first objective of the study on which this paper is based was to determine the driving factors for irregular migration. As stipulated in this study there is no clear answer to the reasons of irregular migration. Table 2 presents these factors as pointed out by the IRMS themselves. The results show that the leading factors for irregular migration in the study area include, land scarcity in their country of origin and the incentives given by smallholder farmers in Kasulu; this was reported by $95 \%$ of the respondents. The results also show that looking for employment as cheap labourers in agriculture was another reason for irregular migration; this was reported by $87.5 \%$ of the respondents. Social and cultural unrest in the country of origin were reported by $14 \%$ of the respondents, while $9 \%$ of the respondents cited looking for permanent residence as among the reasons for irregular migration. Other reasons are as shown in Table 2. According to Bojadžijev (2005) irregular immigration may be prompted by the desire to escape civil war or repression in the country of origin such as persecution, frequent abuse, oppression, and genocide which opens up a new social space and fields of conflict in the host country.

Through the FGDs and in-depth interviews, it was pointed out that when refugees face restrictions in relation to income generating activities in the refugee camps they are often left with no other choice but to compete for jobs in the host communities. Consequently, the above results into smallholder farmers getting cheap labourers who are then used in farm expansion. The quote below supports the reason for having IRMs in Kasulu District:

"...Such things as lack of travelling documents and freedom of movement outside refugee camp, lack of both work permit and freedom of engaging in any paid or unpaid activities are some of the factors for irregular migration" (A 32 years old male, Mvugwe village).

Other factors as mentioned by discussants included lack of refugee identity cards, inadequate food and other humanitarian aid issued in the camp, these collectively forced them to irregularly get out of their camps in search of casual employment and sometimes they establish permanent residence outside refugee camps. The findings are similar to those provided by Düvell and Jordan (2003) who report that IRMs sometimes manage to live undiscovered for many years, gain relatively comfortable living standards and become active members of the host society whilst still being liable to detention, removal or deportation once identified. The results conform to what was pointed out by some key informants as shown in the following quote:

"Life is not as simple in Burundi as some of you think. I experienced land problems before even we fled to DRC and later to Tanzania. When I lived with my parents in Burundi, we did not possess or inherit land. Our life in Burundi was more or less the same as servitude under the system known as "Nyarubanja system". My parents and entire family were forced to live and work as cheap labourers, farming and grazing cattle for a certain Hutu man who in turn used to pay us in-kind under the condition that the land was to be left to us, so that we could build and conduct our own farming. However, once we terminate the contract everything remained the property of the owner (Hutu man). "There are still lots of Burundians who live under stressful conditions, widespread poverty, and have limited access to job opportunities and land for cultivation" (A 33 year old IRM, Kitanga village).

According to Ramsey (2010) the country's social problems affect the indigenous minority, the Batwa people to an even greater extreme than the general population. The Batwa continue to live on the margins of society, suffering the highest rate of poverty, 
unemployment and discrimination in Burundi. Similar incidences were also reported by another key informant who had this to say:

"I was very young to exactly recall the killing of my parents and the resultant details regarding my flight story. I remember fleeing to Tanzania due to genocide in Burundi and when I returned from grazing my parent's cattle, I found no one at home except my father's decapitated head which had been stabled with a sharp object suspected to be machete. I was really scared, trembled and immediately I started running. I heard gun fire behind me. I managed to reach Kitanga villageTanzania with my foster grandmother whom I met by chance as we were running to Tanzania. Although we don't have permission allowing us to live legally in Tanzania, we are living peacefully while serving local smallholder farmers as cheap labourers. I am not willing or ready to be repatriated to Burundi because we heard that our perpetrators are still holding our land and I fear being killed by the same upon my return to Burundi. "I have property here in Tanzania which includes land and a few cattle, and I am married and blessed with five children." (A woman aged 36 years old from Kitanga village).

The study findings are being in line with Vollmer and Düvell (2006) who point out that reasons for being an IRM may change over time, this can happen for many reasons such as accidentally overrun their permission to stay in the country of exile or as a result of the complicated or lack of knowledge on immigration rules. Similar evidence was given during a face to face interview with one of the key informants who said:

"I fled to Tanzania from Burundi in 1993 due to political and economic turmoil. While in a refugee camp, I was approached by one of the opposition political party followers to contribute towards the battle field in Burundi. In 1994, I joined them and spontaneously repatriated back to Burundi without surrendering my ration card which assisted me in getting food and non-food items in the camp. After independence of Burundi in 2005, we, former rebel soldiers, were reintegrated into the government army and I was transferred to Ngozi region as my working Station. This was my home place, one evening after getting drunk, I went to visit my father's land and found those who had killed and taken our land still possessing it. I was in full military uniform and armed. I lost my temper and avenged my parent's death by killing two of those who killed my parents. I returned to the camp and hid, a day later, I heard police were conducting investigations over the killings and out of fear being arrested, I fled to Tanzania where I went directly to the refugee camp and found card exchange exercise in progress, where I activated my ration card and continued enjoying international protection as a refugee. However, I didn't stay in the camp for long as I feared being tracked down by police and went to hide in a nearby local village in Kibondo District. After the closure of the Nduta Camp and relocation of refugees to Mtabila, I established myself in the camp. But I seldom stayed there as I spend most of the time in the local villages in Kasulu District where I work as a cheap labourer on farms and in logging business. The hut in the refugee camp is there just to guarantee me the food and non-food items given from time to time which I sell to Tanzanians. Even if I live in the local community, most of the time I spend on the farm with fellow refugees as my host is not comfortable to let us live with him in the main village due to lack of proper documents (a Man aged 45 years old from Nyachenda village).

Further to the above respondent's explanations, AlixGarcia (2007) indicates that prior to 1993, refugees in Kasulu District were largely assimilated into local communities and most of them were left in local villages to date without a legal document allowing them to work, travel or reside. Generally, during the conduct of this study, it was noted that some of these IRMs interviewed were those who entered the country legally as refugees but remain irregularly in the country. During the FGDs, it was revealed that some of them were unwilling to tell the truth as to whether or not they were former refugees from one of the refugee camps; probably because they thought that the information would lead to their arrest, detention and deportation. One of them accidentally dropped down his valid ration card issued to refugees in the camp in the course of discussions.

Observations from the FGDs also show that the majority of IRMs have never possessed travel documents or work permits. The reasons given during the FGDs were that some of them were living near the border and there is no border post in both countries that was close, and where they could have reported for visa processing, the border posts are about $60 \mathrm{~km}$ away from their village. Concurrently, the immigration office in Burundi where they could apply for travelling documents is located very far from their home. It is also too expensive to get a book passport whose cost ranges from BIF 250,000 to 300,000 , which is equivalent to 255000 to $305000 \mathrm{Tsh}$ (Tanzanian Shillings). Travel cost to the main office in town was another impediment associated with corruption in one hand and impoverishment on the other:

"It is not easy to get a passport in Burundi due to corruption. After all, how can I bother applying for a travel document while I spend hardly fifteen minutes to reach Tanzania?" (A 29 years old IRM, Mvugwe village)

The above statement is similar to the observation by Transparency International (TI) (2007; 2010) which explains that corruption is widespread in Burundi and impedes the ability of the government to perform its basic 
Table 3. Likert scale attitude results towards irregular migrants $(n=80)$.

\begin{tabular}{|c|c|c|c|c|c|c|}
\hline \multirow{2}{*}{ Statement } & \multicolumn{3}{|c|}{$\begin{array}{l}\text { Farmers employing irregular migrants } \\
\qquad\left(n_{E}=40\right)\end{array}$} & \multicolumn{3}{|c|}{$\begin{array}{c}\text { Farmers not employing Irregular } \\
\text { migrants }\left(n_{N E}=40\right)\end{array}$} \\
\hline & $\begin{array}{c}\text { Disagree } \\
(\%)\end{array}$ & $\begin{array}{l}\text { Undecided } \\
(\%)\end{array}$ & $\begin{array}{c}\text { Agree } \\
(\%)\end{array}$ & $\begin{array}{c}\text { Disagree } \\
(\%)\end{array}$ & $\begin{array}{c}\text { Undecided } \\
(\%)\end{array}$ & $\begin{array}{c}\text { Agree } \\
(\%)\end{array}$ \\
\hline Irregular migrants are not burden to the governments & 67.5 & 10 & 22.5 & 57 & 27.5 & 15 \\
\hline Employing irregular migrants will strengthen the economy of Tanzania & 55 & 15 & 30 & 55 & 20 & 25 \\
\hline Irregular migrants have not created any enmity among local community members & 67.5 & 2.5 & 30 & 72.5 & 5 & 22.5 \\
\hline Smallholder farmers trust irregular migrants & 42.5 & 15 & 42.5 & 45 & 22.5 & 32.5 \\
\hline Smallholder farmers create conflict on natural resources over irregular migrants & 62.5 & 15 & 22.5 & 75 & 7.5 & 17.5 \\
\hline Irregular migrants deserve land for farming & 65 & 12.5 & 22.5 & 70 & 22.5 & 7.5 \\
\hline Presence of irregular migrants will not attract more irregular migration & 92.5 & 5 & 25 & 87 & 2.5 & 12.5 \\
\hline Irregular migrants will voluntarily repatriate. & 85 & 2.5 & 12.5 & 85 & 5 & 7.5 \\
\hline
\end{tabular}

functions. In 2007, Burundi ranked 131 out of 179 countries in the Transparency International corruption index, to make matters worse in 2010 it dropped to 170 out of 178 countries. In connection to the reasons stated above, another respondent was argued that they were financially incapable and that it was unwise to resort to criminal activities for the purposes of acquiring wealth or travel documents as shown in the following quote:

"We don't fear the outcome, better be arrested, detained or expelled rather than stay in Burundi in rampant poverty; as human beings, our children need food, education, health care, clothing and other essentials of life but where shall we get them"? "It is extremely difficult to make ends meet, start business without capital, land is scarce and when available it is not productive. In addition, casual labour is scarce compared to Tanzania where even if you don't get permanent or temporary employment, land is available, you can either be employed as a cheap labourer or be self-employed and life goes on" (a 39 years old man from Kagera-Nkanda village).

The verbal testimony was in conformity to what USDS (2011) reported that children and young adults in Burundi have been coerced into forced labour in small farms or informal commercial activities. The report also claimed that some of the traffickers are the victim's family members, neighbours or friends who under the pretext of assisting with education or employment opportunities lure them into forced labour.

Witchcraft was mentioned during the FGDs as one of the reasons which led to irregular migration of migrants from Burundi to Kasulu. Therefore, this scenario reflects the observation reported by AFP (Agency France-press) (2008) as cited by news24 Archives (2008) that, belief in witchcraft is widespread in some parts of Burundi and a number of people are killed each year under suspicion of participating in sorcery. The killings continue because the perpetrators are rarely properly punished. Other reasons for irregular migration as discussed by the FGDs participants include intensification of security in Burundi where criminals flee Burundi and seek refuge in Kasulu.

\section{Attitudes of smallholder farmers on irregular migrants}

Responding to the second objective of this study, data was collected using a five point Likert scale which comprised 8 statements. However, for easy follow-up the five point scale was later reduced to a three point scale by grouping agree and strongly agree together and likewise disagree and strongly disagree, the results for this are presented in Table 4. Nonetheless, the results for the five point Likert scale are presented in Table 3. Generally results in Table 3 show that the attitude of smallholder farmers using and those employing IRMs against IRMs were mixed as indicated in Table 3. The respondents were asked to say whether they strongly disagreed, disagreed, undecided, agreed, or strongly agreed with each statement. The descriptive statistics was used to 
Table 4. Three categories of overall attitude towards irregular migrants $(n=80)$.

\begin{tabular}{|c|c|c|c|c|}
\hline \multirow[t]{2}{*}{ Attitude scale } & \multicolumn{2}{|c|}{$\begin{array}{l}\text { Smallholder farmers employing irregular } \\
\text { migrants }\left(n_{E}=40\right)\end{array}$} & \multicolumn{2}{|c|}{$\begin{array}{l}\text { Smallholder farmers not employing irregular } \\
\text { migrants }\left(n_{N E}=40\right)\end{array}$} \\
\hline & Frequency & Percent & Frequency & Percent \\
\hline Favourable attitude & 12 & 30.0 & 4 & 10.0 \\
\hline Indifferent attitude & 1 & 2.5 & 1 & 2.5 \\
\hline Unfavourable attitude & 27 & 67.5 & 35 & 87.5 \\
\hline
\end{tabular}

analyse the information on attitude of the respondents towards IRMs whereby scores on individual statements and overall scores on all the statements were used to determine the extent of their attitudes.

The field findings in Table 3 show that with the exception of the responses to the fourth statement having 42.5 and $45 \%$ of smallholder farmers employing and those who do not employ IRMs, in each statement disagreed with almost all the statements that sought to measure their attitude towards the presence of IRMs in their area. Thus, this finding confirms that although IRMs are living with and employed by smallholder farmers yet, both smallholder farmers have a negative attitude on their presence. The study findings are in line with Berry (2008) who stated that villagers were unhappy with IRMs as they come to steal their crops in farms.

The results on attitude towards IRMs as presented in Table 3 also show that 67.5 and $57 \%$ of smallholder farmers employing and those not employing IRMs disagreed with the statement that IRMs are not a burden to the national security. While 22.5 and $15 \%$ of the respondents in the same categories agreed with the same statement above. The findings also show that 55 and $55 \%$ of both smallholder farmer employers and nonemployers of IRMs respectively disagreed with the statement that employing IRMs will strengthen the economy of Tanzania.

On the other hand, results in Table 3 show that 30 and $25 \%$ of the respondents in the same categories of smallholder farmers agreed with the statement that using IRMs will strengthen the economy of Tanzania. These results were not different from those obtained from the statement that IRMs have not created any enmity among local community members, 67.5 and $72.5 \%$ of the respondents in the two categories of smallholder farmers disagreed with, while 30 and $22.5 \%$ of the respondents in the two categories of smallholder farmers agreed with this statement that IRMs have not created any enmity among local community. The above seem to somehow agree with Rezouni (2010). According to Rezouni illegal/irregular migration can have both positive (benefits) and negative aspects (disadvantages) and that these may be both to the destination and sources countries. For example, while reducing the number of unemployed in the departure countries it may increase that rate in the host countries. Therefore, the study area's economy being predominantly agricultural driven means competition for agricultural land between the IRMs and local may arise. However, on the other hand farmers with large farms can easily get cheap labour to work on the farms consequently denying locals possibilities of being employed as casual labourers. Other results are as shown in Table 3. A descriptive analysis was further applied to find the group which had favourable, indifferent and unfavourable attitudes. Since the statements were 8 , if one had chosen favourable attitude for all the 8 statements, he would have scored 40 , that is, $8 \times 5$ equals 40 . Similarly, if one had been indifferent by choosing 3 out of 8 statements, one would have scored 24 , that is, $8 \times 3$ equals to 24 . This means that the minimum possible score was 8 , that is, $8 \times 1$ equals 8 . Therefore, 8 to 23 points denoted unfavourable attitude; 24 denoted indifferent attitude, and 25 to 40 points denoted favourable attitude. Table 4 shows that the proportion of those who had favourable, indifferent and unfavourable attitude were $30,2.5$ and $67.5 \%$, respectively for smallholder farmers employing IRMs and $10 \%, 2.5 \%$ and $87.5 \%$, respectively for smallholder farmers not employing IRMs. The results are consistent with those in Table 3 which indicate that smallholder farmers generally are not comfortable with the presence of IRMs in their areas. This implies that regardless of whether they employ IRMs or not more than a half of the respondents (both smallholder farmers in the same categories) had more negative than positive attitude towards IRMs.

The results on attitude of the respondents reported during face to face interview with key informants were similar to those reported during the FGDs. Some of the issues reported include accusations of theft of crops and cattle, destruction of crops such as maize, beans and cassava, grazing livestock on their farms and destroying the environment due to logging activities, charcoal making and disruption of farming activities. Other problems often mentioned and which were caused by IRMs include banditry, car hijacking and deforestation. The findings above are consistent with those by Rutinwa (2003) who pointed out that, it was uncommon for locals to hire refugees to work on their farms, because the former accused the latter of theft of crop from farms of local smallholder farmers living along the border areas.

Observation from FGDs further showed that there was 
no direct evidence of IRMs being more active in criminal activities than the rest of the population in Kasulu. However, both categories of smallholder farmers were somehow not happy with IRMs due to their misbehaviours, as it was mentioned by the respondents during FGDs that IRMs were involved in activities such as robbery, homicide and acquiring of land illegally. Furthermore, the study revealed that, smallholder farmers employing IRMs were reluctant to finger point and accuses IRMs over criminal activities because they still need them in their agricultural activities. The above seem to conform to Chappell et al. (2011) who have pointed out that Irregular migration does pose significant social and political challenges to the destination countries. In addition, Rezouni (2010) has pointed out that illegal/ irregular migration can lead to organized crimes and flourishing of violent gangs thus posing some potential threat to security in destination countries.

During the interview the respondents also reported that IRMs sometimes demand things such as good feeding, clothing and extra payment for drinking local brew which smallholder farmers cannot afford. Expressing their attitude against IRMs, the respondents during the FGDs disclosed that sometimes IRMs were not attached to one smallholder farmer rather they would serve different farmers at different times in the same season, for example, a wife of an IRM enter into a contract with a different smallholder farmer apart from the one contracted by her husband. In order to attend to both jobs, they jointly rotate from one farm to another in the same season as a result creates misunderstandings among smallholder farmers. This observation seems to suggest that IRMs are paid meagre wages and that they have to look for extra work to augment their income. Reacting during FGDs, the respondents claimed that, although IRMs were coming to Kasulu aimed at getting employment as cheap labourers some of them were migrating to Tanzania with the entire families to seek for permanent residence illegally. In connection to these findings Koser (2005) argues that unless the economic rationale of irregular migrants is properly understood, efforts to manage them are unlikely to succeed.

Observation from the FGDs further show that IRMs were sometimes viewed as a burden to the government due to frequent operations carried out against them. They further argued that, the cost of both time and money spent in these operations could have been used in other sectors such as agriculture, education or health. They also claimed that sometimes IRMs have been deliberately registered as voters or applied for birth certificates either for themselves or for their children knowing that they were not Tanzanians.

It was also highlighted that IRMs grabbed land, bought or inherited it from fellow Burundians who have been living in Tanzania for many years. This generally suggests that the local people are being deprived of the right and opportunities for land ownership, thus causing endless chaos and conflicts between Tanzanians and IRMs on land management and other natural resources. In line with these findings, Bastian and Don (2009) stated that, the forces that determine the scale of international migration is powerful. And that, growing disparities in the level of prosperity and human security are experienced by different societies and the ability to modify them is still limited. Findings from the study also show that forests, soil, and water are essential elements in supporting the livelihoods of many poor local smallholder farmers. However, the observed massive land clearing for agriculture related activities which is largely a result of deepening poverty and the provision of cheap labour in the form of IRMs has been blamed for accelerating deforestation. According to UNEP (2005) refugees and locals had to travel much greater distances to find firewood and wood for construction than was necessary 10 years ago, this is because some people have chosen to illegally cut down living trees, thus contributing to the degradation. These observations suggest that changing of the landscape is likely to occur leading to soil erosion and threatening agricultural production among smallholder farmers.

Based on the above, If no immediate measures are taken, then as it is argued, free immigration of IRMs in connection with culture of shifting cultivation done by both local smallholder farmers and IRMs in the areas with huge forest and bushes could weaken state regulation and the ability to control and plan over both agriculture activities and IRMs. A similar trend of constraints was observed by Veney (2007) who admits that, presence of the IRMs has positive and negative impacts on host communities; the negative impacts include environmental degradation, among other problems.

Expressing the hostility created along the border between Tanzania and Burundi, IRMs during the in-depth interview it was pointed out that after they get paid for their labour and while on their way back to their country they are frequently ambushed by robbers claimed to be Tanzanians who take all the money paid: This in return compels IRMs to avenge against Tanzanians who go to Burundi for business and other purposes by ambushing and robbing them. These study findings suggest that unless security is strengthened along the border of both countries, the good relations amongst the citizens of Burundi and Tanzania living along the border may be at risk of being strained.

Observations from the FGDs further show that, accountable and responsive governance on IRMs at local level is often weak; this has been attributed to both impaired social capital and limited financial capacity of the government at local community level. This is simply because the majority of the local smallholder farmers at village level regardless of whether they are leaders, whether they employ IRMS or not, young or old have at one point in time got into conflict with IRMs. The findings are consistent with the findings by Berry (2008) who 
reported that there is a danger in assuming that the interaction between IRMs and smallholder farmers depends only on economic improvements, this can actually encourage competition on production and conflict that leads to isolation and segregation between smallholder farmers and IRMs.

The study findings are also consistent with those of a study by Duvel (2006) who reported that sometimes, irregular migration is a product of a government failure to meet the immigration needs of the country by providing adequate opportunities to travel and staying once IRMs have settled. In explaining their concerns over IRMs, some of the key informants, during the face to face interviews point out that, the presence of IRMs has led to a reduction of prices of agricultural produce and has lowered employment wages for local labourers:

"Employment opportunities for local people living along the border depends on people who come directly from Burundi, but, "because of involvement of irregular migrants in agricultural related activities here in Kasulu, labour costs have gone down as well as the prices for both farm and non-farms products. This is because, irregular migrants engage in both marketing of crops and cheap labour" (A 46 year old man, Mvugwe village).

According to Gordon (2007), irregular workers in the destination country tend to add and compete with the pool of unskilled labourers and are generally successful in finding employment by accepting lower wages unlike the native workers.

\section{Problems irregular migrants face in their interaction with local community}

Table 5 shows that, more than three quarters $(77.5 \%)$, of the IRMs interviewed said that lack of work and residence permit have led them into serious problems related to immigration status, Less than three quarters $(70 \%)$ of the IRMs stated that they have difficulty in doing self-reliance activities. In line with the stated problems, $65 \%$ of the respondents reported that they lacked freedom to be hired in the agricultural activities for similar reasons related to illegal stay in Kasulu. The results also reveal that three quarter $(75 \%)$ of the IRMs reported that, lack of social services such as schools for children and healthcare services were among the problems prevalent in the studied area. About, $75 \%$ of the IRMs reported to not having formal contracts and were underpaid. Whereas alleged of theft and robbery constituted $22.5 \%$ of respondents. The remaining over a tenth $(12.5 \%)$ of the IRMs said that they lack refugee identity cards thus leading to frequent arrests and detentions once they venture out of the camp.

During the FGDs, the participants reported to have been exploited, facing physical and emotional abuse, being poorly paid and some of them become victims of human trafficking where they get transferred to other regions against their will to serve in agricultural activities as cheap labourers. According to McKay (2009), the majority IRMs are lowly paid and because of low wages are often associated with high levels of exploitation and criminals thus become an important part of millions of vulnerable workers employed in the informal sector and who are striving to seek their rights.

During the face to face interviews with key informants, some IRMs shed light on corrupt incidents that take place along non-official borders and within the village. They claimed that they were ordered by Militiamen who stay along the border to give them bribe with money ranging from 3000 to 5000 Tsh as entrance fees; whoever declines to pay is denied entry into the country. The respondents also reported to have been forced by village leaders to pay them between 10000 to 30000 Tsh as permit to stay in the village or as a land fee for cultivation. The above findings are similar to what has been reported by UNDP (2009). According to UNDP irregular migration can be influenced by geographical proximity, employment opportunities, and ease of entry into a country. However, irregular migrants can on the other hand find themselves at risk of suffering unemployment, insecurity and social marginalization: at times they are seen as the cause of these problems. During in-depth interview one of the respondents confessed to have been underpaid and overworked by smallholder farmers:

"Our payment is fixed and it ranges from 250,000 to 450000 Tsh in a season. Besides, we are given only two days a week to rest, during local common market days. But also we have no limit of land to farm as this is subject to the employer's descretion, we can even till more than ten hectares for the same payment. Morever, payment is done after the crops have been harvested and sold". (An IRMs aged 34 years from Mvugwe village)

It was also reported by the FGDS participants that while waiting for their payment, IRMs were taken by their employers to perform other tasks regardless of whether or not they were paid for these activities. Generally, they were asked to render their services in return for the food they consume while waiting for payment. Discussants claimed that, they were reluctant to decline because they knew any kind of resistance could amount to having them arrested and deported for their illegal immigration status. This finding is similar to that of Duvell et al. (2008) that IRMs cannot normally form non-government organizations, such as trade unions, civic associations or become members of any parties, a situation which could enable them negotiate for better treatment in the provision of labour services. In connection to the above findings, during in-depth interview, one IRM said that:

"We, irregular migrants, are particularly vulnerable as a group because our irregular status prevents us from asking for social and legal assistance out of fear of being 
Table 5. The factors affecting irregular migrants $(n=40)$.

\begin{tabular}{lcc}
\hline Statements & Frequency & Percent \\
\hline Lack of freedom to be hired. & 26 & 65.0 \\
Deprived of self-reliance activities & 28 & 70.0 \\
Lack of social services & 30 & 75.0 \\
Alleged of theft and robbery & 10 & 25.0 \\
Lack of refugee identity cards & 17 & 42.5 \\
No formal contract and underpaid, & 30 & 75.0 \\
Lack of working and residence permit & 31 & 77.5 \\
\hline
\end{tabular}

identified, caught or prosecuted and thereafter imprisoned or deported. For this reason, we don't want to take action against our employers lest we find ourselves in jeopardy". "We sometimes spend a day in the farm without food and nowhere to seek for food as we are not living in the community, our temporary houses are scattered and far from each other, we have neither phones nor any other means of communication, no social services for ourselves and for our children such as school and official health related centre". (A woman aged 40 years of age, KageraKanda village).

According to Birman (2005) IRMs are characterised by some more subtle ways of vulnerability, including illiteracy or suffering from economic or social disadvantages and because of these characteristics these people are exposed to greater risks than other groups by virtue of their membership to the oppressed, powerless, unemployed and traumatized groups.

\section{Testimonies on various factors affecting irregular migrants}

In order to get more details on the problems facing IRMs in Kasulu District, respondents were asked to give more information related to their flight history and the link between their problems and smallholder farmers. The sub section presents testimonies from few IRMs who gave their flight story. The responsible IRMs were coded in order not to compromise their confidentiality. Therefore, IRM were assigned to their corresponding numbers which implied irregular migrants from Burundi. For example, the first interviewee hereby referred to as IRM 1, the second IRM 2 and so on.

\section{Box 1: IRM Testimony}

"I can't remember how my parents fled from Burundi to the DRC. I was born and raised in the DRC; but my father told me that prior to their departure to the DRC, our house was attacked by grenades and they escaped and fled to the outskirts of the village. I fled DRC to Tanzania in 1997 following the outbreak of war caused by escalating conflict between different armed opposition groups in DRC. I faced difficulties during my flight as I lost my parents and siblings. In 2006, I returned to Burundi and was given a small portion of land to live on. However, I spent only eight months in Burundi before I returned to Tanzania and integrated locally in one of the local villages where I have been working as a casual labourer."

"In Burundi, land is scarce; it is hard to find many people possessing more than two hectares in one block. People own several pieces of land which are scattered and most of them are not arable. It is hard to get a job or be self-employed. If I get a chance to be employed as a casual labourer in Burundi, payment is a problem, we are paid 5000 BIF per hectare without extra benefit while in Tanzania payment for a season ranges between 250,000 and 450,000 Tsh, depending on the nature of the contract, and some of cheap labourers are even paid money and food, some are given land in advance as form of payment. Equally, others may be given a one year contract which includes clearing the farm, cultivating, planting up to harvesting; others may commit themselves for some of the above activities and off they go".

According to IRM1, hardship of life, shortage of land, unemployment, lack of incentives in farming and underpayment were the main reasons for his migration to Tanzania. On why he didn't have a legal travel document, he said it was difficult to acquire such documents because of bureaucracy and corruption in Burundi; they are forced to pay 20,000 BIF for a two day permission to travel to Tanzania. According to Bastian and Don (2009), forces that determine the scale of international migrations are very strong and that growing disparities in terms of prosperity and human security is experienced by different societies and the ability to modify them is very limited.

\section{Box 2: Testimony for IRMI continued}

IRM1 continue to say, "My home was about $200 \mathrm{~m}$, from the border and through the assistance of a Tanzanian friend. I was introduced to the security guards at the border who demanded payment of 5,000 Tsh. This 
payment allows us to enter Tanzania does not guarantee neither a work permit nor resident permit and there is no receipt issued. There are several means by which fellow Burundians use to get into Tanzania. Some enter Tanzania through unguarded informal crossings during common market days pretending to be Tanzanian as they are fluent in both Kiswahili and The local vernacular language $\mathrm{Ha}$. I left Burundi due to diverse reasons connected to socio-economic and political instability. When I hear on radio about the ongoing civil and political turbulence in my country, I recall the past and find myself unwilling to return to Burundi. I know my father was either killed due to his refusal to support one of the political parties or because of land related problems."

"I am fully acknowledging that I live and work illegally in Tanzania but, there is no way out because I don't face any problems except when I am caught by immigration officers, the police or forest officers. Our employers and other villagers assure us of security for our property, housing, residence and payment for the duration of our stay in Tanzania. Apart from farming, I also participate in logging" (A 29 year IRM, Kagera-Nkanda Village).

However, IRM1 has faced some problems with his employer in Kasulu; these include underpayment contrary to what was agreed and lack of food while living in the farm areas. Nonetheless, IRM1 refrained from reporting them to the authorities and according to IRM1 this was due to that, irregular migrants have limited rights while in exile. IRM1 declined to report the case to the police because he knew taking the case to court would lead to risks such as arrest, detention and deportation for illegal entry and residence. The testimony by IRM1 for the reasons of his fleeing to Kasulu District is due to violation of human right as stipulated by UDHR (1948) which states that "All human beings are born free and equal in dignity and rights. They are endowed with reason and conscience and should act towards one another in a spirit of brotherhood" (United Nations, Undated, 2016).

\section{Box 3: IRM2 testimony}

"I previously left Burundi in 1993, together with my neighbour after my parents were shot dead during the war. I managed to escape when our hideout in the forest was ambushed. During the incident, I was shot and that led to the amputation of my right leg which is still painful to date. Those who survived the killings brought me to Tanzania where I was hospitalized in one of the hospitals in the refugee camp. In 2005, I voluntarily got repatriated to Burundi but contrary to my wish I was kept in a newly established peace village for more than a year without being given a plot of land to build my house. Life became difficult and I decided to return to Tanzania. Since I was familiar with local villages in Tanzania I didn't go to the refugee camp rather I went to one of the villages and engaged in farming as a cheap labourer. Generally, I came to Kasulu to look for employment as a cheap labourer as I couldn't find both employment and land to rebuild my life in Burundi. However, life is not simple while working as a cheap labourer in Kasulu. We are sometimes forced to live in grass thatched houses within the forest or near the farm land" (A 34 year old IRM, Nyachenda Village).

The testimony given above is consistent with the results by Bastian and Don (2009) who pointed out that, some people who become IRMs cannot return to their country of origin even if they want because of unsafe conditions, lack of documentation needed to travel, or refusal of their country of origin to accept them. They find themselves homeless, become stuck, and destitute, cannot resolve their irregular migration situation and hence reliant on support sometimes provided by local charities or churches (Koser, 2000).

\section{Box 4: IRM3 testimony}

Narrating his flight story and living conditions in Kasulu, IRM3 has this to say. "I left Burundi in 1993, following social and political unrest in Burundi. Although my village by then had not yet been ambushed by either government or rebel soldiers, villagers were nonetheless terrified by the gun shots from a neighbouring village. "My father forced me and the rest of the family to flee to Kitanga village in Tanzania where we have established our residence. This is one of the villages hosting many Burundian refugees who didn't reach the reception centre or Mtabila refugee camp." "IRM3 continue to say, "all of my family were repatriated to Burundi in 2006 after the Tanzania Government conducted an operation for irregular migrants. Since 1993 when we arrived in Tanzania, I have neither had nor attempted to apply for any legal document from the government which could allow me live and work peacefully in Tanzania. Since then, I have been working as a casual labourer in a farm and sometimes have been spending little time working on my own farm, which I inherited from a fellow Burundian. I wish to live in Tanzania permanently but the problem I am facing is how to obtain a permit to live legally and peacefully. My life is in danger, as I risk being arrested by immigration and forest officers who prohibit people from entering and doing any business in the forest reserves. We sometimes spend the day hiding awaiting the departure of these officers. Since 1993, when I arrived in this village I have neither gone nor wished to return to Burundi or in the refugee camp.

"IRM 3 continued to say that, "I left Burundi when I was young. I have spent most of my time in Tanzania doing casual work as a cheap labourer with different smallholder farmers. I have closely integrated with the Tanzanian 
culture, I speak Ha language fluently more than even my venacular language. I have a plot for my own crops and I am married to a Tanzanian woman sincerely I am not ready to go to Burundi. I would rather die here in Tanzania. How can I go and leave my family in Tanzania? (A 40 year old IRM, Mvugwe Village).

\section{Box 5: IRM4 testimony}

"I fled to the DRC from Burundi in 1993 together with my foster parents following generalised violence in Burundi. I don't know whether my parents were killed or not because since we fled separately I have never heard from them. We didn't stay long in DRC, as the war broke out due to political differences between Kabila and his opponents during which my foster parent was killed and left me with no one to save my life until when I met one of my Burundian neighbours who brought me with her to Tanzania. She advised me not to return to Burundi as those who killed my parents are still occupying our land and I risk being killed upon return to Burundi. I hear on radio that people are still being abducted and killed in Burundi."

Responding as to why he left Burundi he said. "Initially the problem was associated with both ethnicity between Hutu and Tutsi and witchcraft as they alleged my parents were witches. The problem intensified and later on our houses were invaded and burnt down. I saw the perpetrators with local weapons such as swords, spears and axes. I was seriously wounded, but at least I escaped the killing and fled to the DRC and then to Tanzania. It took me three weeks before I reached the refugee camp where I stayed for one year without being regularised as a refugee. Following social exclusion of refugees at the camp, I became integrated into one of the Tanzanian villages where I had been working as a cheap labourer since 2001. I married a fellow Burundian and we are blessed with four children. I have my own house and land acquired illegally. Because I left the camp with my ration card, I had in those years received and enjoyed all the rights as a refugee including receiving food and nonfood items given in the camp. Explaining why he does not want to return to Burundi IRM4 had these to say, "Burundi is a small country and land is scarce compared to its population and is overused. And due to our problems I appeal to the concerned Tanzanian authorities to consider allowing us (IRMs) enter, travel and reside without legal documents, because what we are looking for is just little money to make ends meet together with our families. I have five hectares of land with different types of crops and three cheap labourers who are fellow irregular migrants" (A 38 year old IRM, Mvugwe Village).

In connection to the above testimony, UNHCR (2004) argues that the impacts of IRMs are both positive and negative. However, the dynamics between positive and negative factors are complex and vary depending on several factors, including the political economy of hosting countries and the nature of host-IRMs relations. Even when IRMs situation creates economic opportunities for both the displaced and their hosts, there can be winners and losers.

\section{Box 6: IRM5 testimony}

“I can't exactly remember my flight to Tanzania but I recall arriving in 2000. Before I fled to Tanzania I was once caught, beaten by rebels because I refused to join them in the battle field, that is, against the Burundi government. I was held captive for nine months, during which I was sodomised and brutally tortured. I survived through God's mercy. Although I have lived in Tanzania for several years since then I have neither claimed for my refugee status nor has my individual refugee status been determined by any authority. I didn't present myself for refugee status identification for fear of being under restriction of movement in and out of the camp. Hence, I decided to live in the local village engaging in agricultural activities and I have never returned to Burundi due to land problems and difficulties of life.

"My biggest challenge is where I shall be tomorrow in case the government of Tanzania decides to expel me from where I live. Being an IRM is equivalent to being a sub human;" "I am concerned over my illegal and temporary residence status in Tanzania as well as returning to Burundi" "Home is where I have slept today while waiting for my death". My land in Burundi is already occupied by those who remained behind and I don't know where to lodge my claim. Indeed irregular migration stops us from investing anything on a long term business, I can't engage in business or construct a permanent house, get better and quality education for myself and our children, legally own a large farm and similar projects. I live in a state of limbo and I often depend on others to find solutions for my plight." "Social services are another challenge facing us (IRMs): there are rough and impassable roads towards the areas occupied by IRMs. There is neither hospital nor a health centre, no school for the children as schools are situated about $20 \mathrm{~km}$ away from the main village. IRMs who seek to attend primary and post primary education in Tanzania are subjected to the same formalities as other foreign students including the need to apply and pay for a study permit otherwise remain vulnerable for arrest and deportation. Such resident permits are expensive and hard to obtain. In fact, I am not ready to go to Burundi due to the experiences I went through. I heard that antagonism between Hutu and Tutsi still exists in Burundi. I own nothing and I was told that our own land has been allocated by the government to someone else who has a title deed" (A 30 year old IRM, Kitanga Village). 
Based on the testimonies given by the IRMs, one can sense that uncertain nature of the IRMs livelihoods both in host and country of origin regardless whether they are living in remote area; have access to employment opportunities, property rights and restrictive laws (Mark, 2009). Often compel IRMs to look for alternative options as cheap labourers outside their country of origin. As a result a new type of social movement is formed which creates a new social contact and conflict in the host country. In connection to that, observation form testimonies do not suggest the possibility of reducing the magnitude of IRMs and it is important to be realistic about prospects of IRMs in Tanzania. Obviously, irregular migration by Burundians will continue for the foreseeable future as explained by Bojadžijev (2005) that while mobility in the form of labour migration is seen as a source of exploitation to the country of exile; on the other hand, it is seen as a panacea to relations of exploitation and dominance from the country of origin. Further to the findings above, Bastian and Don (2009) points out that some IRMs may willingly stay without legal documents, because they fear conflict in their country of origin and they neither conform to any stereotypes nor their individual circumstances affect what they do and it is usually very difficult for them to resolve their status and be re-issued with the permit they need.

\section{CONCLUSIONS AND RECOMMENDATIONS}

A number of conclusions are hereby drawn from the above major findings. First, there is a growing recognition of the long-term and short term existence of IRMs in Kasulu District and it is better to accept that the state has, nevertheless, failed to control irregular migration effectively and efficiently. The existence of IRMs in Kasulu is to a great extent connected to economical, social-cultural and political turmoil in their country of origin. Secondly, it is concluded that, despite criminal acts done by IRMs. The majority smallholder farmers are reluctant over IRMs, This basically justify that, there is inadequacy information sharing about IRM workers and their aftermath to local community. The general inability to effectively manage IRMs, lack of strong internal control and improper data collection to both employed and unemployed IRMs is a cause of alarm. Lastly, it is concluded that, there are many factors affecting both smallholder farmers and IRMs and this is due to lack of effective and consistent approaches from the national to local levels that address the concerns of both IRMs and the smallholder farmers. The challenges facing both smallholder farmers and IRMs are expected to last longer, if immediate solutions will not be taken timely.

Based on the study's conclusions, the following are recommended. First, it is recommended that, the immigration department and other security organs working along the border should establish several entry posts either permanent or mobile one along the country borders to deter IRMs and ease visa issuance process for those migrants wishing to enter the country legally. It is also recommended to village authorities to have special register books for all legal and irregular migrants residing in their area. These registers could help smallholder farmers establish facts of whether a particular migrant has the right to employment or not, hence helping smallholder farmers abide by the country's immigration laws and regulations. Lastly, the study further recommends that, the government at all level should provide intensive training to local community members with special emphasis on migration laws, security and land management. Awareness building that leads to segregation for future potential migrants should be highlighted and addressed.

\section{CONFLICT OF INTERESTS}

The authors have not declared any conflict of interests.

\section{REFERENCES}

Ahlberg A, Runell C (2009). The New Regulation on Labour Immigration. Department of Social Work, Mid Sweden University. P 29

Alix-Garcia $J$ (2007). The effects of refugee inflows on host country populations: Evidence from Tanzania. University of Montana, USA [http://ssrn. com/abstract=836147] site visited on 22/9/2011.

Bastian V, Don F (2009). Irregular migrants the urgent need for new approach. Migration, London. [www.migrationwork.org] site visited on $3 / 5 / 2012$.

Berry $L$ (2008). The Impact of Environmental Degradation on Refugeehost Relations. A case study from Tanzania. Research Paper University of Denver. 151:27.

Birman D (2005). Ethical issues in research with immigrants and refugees. (Edited by Trimble, J. E. and Fisher, C. B.), Handbook of Ethical Research with Ethno Cultural Populations and Communities. Sage Publications, Thousand Oaks. P 3381.

Bojadžijev M (2005). Does contemporary capitalism need racism? [http:// translates. Eipc p.net/strands/02/bojadzijev-strands01en] [04/02/2012].

Düvell F (2006). Irregular migration: A global, historical and economic perspective. Illegal immigration in Europe: Beyond control.14-39.

Düvell F, Jordan B (2003). Immigration Control and the Management of Economic Migration. Organizational culture, implementation, enforcement and identity processes in public services, United Kingdom. P 336.

Düvell F, Anna T, Bastian V (2008). Ethical Issues in Irregular Migration Research, Citizen and Governance in Knowledge-Base Society EU. Research DG, European Commission. pp 36.

Gordon $\mathrm{H}$ (2007). The economic logic of Illegal immigration. Report to the council on foreign relations. [http://www.cfr.org/content/publications/attachments/ Immigration CSR26. pdf] site visited on 3/3/2012.

IOM (International Organization for Migration) (2010). World Migration Report $2010.2 \quad[\mathrm{http}: / /$ publications.iom.int/ bookstore/free/WMR_2010_ENGLISH.pdf] [05/6/2012].

Jacob DG (2009). Refugee Impacts on Host Communities in Western Tanzania. A GIS is and mixed-method geographic analysis. Appalachian State University, Boone. P 30.

Jennifer A (2007). The Effect of Refugee Inflows on Host Country Populations. Evidence from Tanzania, North Carolina, USA. P 36.

Johnson H (2008). Irregularizing Mobility Migrant Narratives and Reframing Irregular Migration. Department of Political Science, McMaster University. P 14 
Kasulu District Council (2010). Kasulu District Profile. District Executive Director's Office, Kasulu, Kigoma, Tanzania. P 18.

Koser K (2000). Asylum policies, trafficking and vulnerability. International Migration 38(3):91-112.

Koser K (2005). Irregular migration, state security and human security: Expert paper prepared for global commission on international migration [www.gcim.org] [22/11/2011].

Mark T (2009). The drivers of immigration in contemporary society: Unequal distribution of resources and opportunities. [http://www.Springerlink.com/con tent/319464 1502768341/] site visited on 2/12/2011.

Mattsson K (2008). De paperslösa och de Anningslösa. Stockholm, Leopard. P 21.

McKay S (2009). Refugees, Recent Migrants and Employment. Routledge, London. P 36.

Mouaatamid B (2010). Overview on South-South Migration and Development Trends and Research Needs in Tanzania. African Caribbean and Pacific Group of States Observatory on Migration, Dar es Salaam, Tanzania. P 17.

News24 Archives, (2008). Four killed in Burundi in witchcraft http://www.news24.com/Africa/News/Four-killed-in-witchcraft-row20080912. [20/11/2016].

NRC (Norwegian Refugee Council), (2006). Report on Human Rights Violations during the Expulsion of Burundians living in Tanzania. Norwegian Refugee Council, Bujumbura, Burundi. P 25.

Patrick T, Geronimo E (2003). Globalization, Labour and Migration. Protection is paramount. International Migration Programme International Labour Office, Geneva. P 2.

Ramsey K (2010). Uncounted: the hidden lives of Batwa women. MRGI (Minority Right Group International). http://minorityrights.org/wpcontent/uploads/old-site-downloads/download-804-Uncounted-thehidden-lives-of-Batwa-women.pdf [20/11/2016].

Rezouni S (2010). Illegal Immigration: Causes, Consequences, And National Security Implications? U.S. Army War College CARLISLE BARRACKS, PENNSYLVANIA 17013.

Rutasitara $L$ (2002). Economic policy and rural poverty in Tanzania. In: Researching Poverty in Tanzania: Problems, Policies and Perspectives (Edited by Kikula, I., Kipolola, J., Shivji, I., Semboja, J. and Tarimo, B.), Mkuki na Nyota Publishers Ltd., Dar es Salaam, Tanzania. pp. 18-26.

Rutinwa B (2003). The Impact of the Presence of Refugees in North Western Tanzania. The centre for forced migration at the University of Dar es Salaam, Final Report. Dar es Salaam, Tanzania. 4:7.

Rutinwa B (2005). Identifying Gaps in Protection Capacity, Strengthening Protection Capacity Project. United High Commission for Refugees, Dar es Salaam, Tanzania. P 134.

TI (Transparency International), (2007). Corruption Perceptions Index 2007. [05/07/2012].
TI (2010). Corruption Perceptions Index 2010. http://www.transparency.org /cpi2010/results [05/07/2012].

United Nations, (Undated) (2016). Universal Declaration of Human Rights. http://www.un.org/en/ universal-declaration-human-rights/ [20/11/2016]

UNEP (2005). Impacts of refugees and internally displaced persons on the environment in Tanzania. [www. unep.org] [12/06/2012].

UNDP (United Nations Development Programme) (2009). Human Development Report 2009. Overcoming barriers: Human mobility and development. http://hdr.undp.org/sites/default /files/reports/269/hdr_2009_en_complete.pdf[19/04/2017]

UNHCR (United Nations High Commissioner), (2001). Refugee Operations and Environmental Management. Oxford University Press, New York. P 315.

UNHCR (2004). Economic and Social Impacts of Massive Refugee Populations on Host Developing Countries, as well as other Countries. EC/54/SC/CRP.P 5

UNHCR (2006). The State of the World Refugees: Human displacement in the new millennium. Oxford University Press, Oxford. P 340.

URT(United Republic of Tanzania) (2010). Immigration Department, Physical. Verification report for Burundian refugees of 1972 living spontaneously in Kasulu district. P 28.

USDS (United State Department of State) (2011). United State Department of State, trafficking in person report-Burundi. [http//www.unhcr.oorg/refworld/docid/4e12ee8e30.html] site visited on $5 / 7 / 2012$.

Veney C (2007). Forced Migration in Eastern Africa: Democratization, structural adjustment and refugees. Palgrave Macmillan, London. P 304.

Vollmer B, Düvell F (2009). Research Briefing Clande Stone Project. COMPAS Oxford, London, UK. P 24. 